\title{
Organochlorine pesticides in lacustrine sediments and tilapias of Metztitlan, Hidalgo, Mexico
}

Laura M. Fernández-Bringas ${ }^{1}$, Guadalupe Ponce-Vélez ${ }^{1}$, Laura G. Calva B. ${ }^{2}$, Isaías Hazamamberth Salgado-Ugarte ${ }^{3}$, Alfonso V. Botello ${ }^{1} \&$ Gilberto Díaz González ${ }^{4}$

1. Marine Pollution Laboratory, Institute of Marine Sciences and Limnology, UNAM; Circuito Exterior s/n Ciudad Universitaria. 04510 Mexico city; Apartado Postal 70-305 México Tel: (55)5622 5765; lf_bringas@yahoo.com

2. Laboratory of Marine Ecosystems, Metropolitan Autonomous University, Campus Iztapalapa. Mexico city 09340, Mexico.

3. Biology School, FES-Zaragoza, UNAM. CAMPUS II: Batalla 5 de mayo s/n Esq. Fuerte de Loreto. Col. Ejército de Oriente, D.F., México.

4. Department of animal and Agricultural Production. Metropolitan Autonomous University, Campus Xochimilco. Mexico city 04960 Mexico.

Received 06-XI-2006. Corrected 09-V-2008. Accepted 26-V-2008.

\begin{abstract}
The organochlorine pesticides (OP) are very stable molecules, due to this stability; they are very resistant in the environment and highly related to fat tissues with a wide diffusion property and an average time life higher then 10 years. We studied sediments (November 2001, April and June 2002) and organisms collected in April and July (2002) from the lacustric zone of Metzitlán, Hidalgo, Mexico. The analysis was performed according to UNEP/IAEA (1982) (sediments) and UNEP/FAO/IOC/IAEA (1986) (organisms) methods. Three chemical families of organochlorine pesticides were identified and analyzed to determine posible toxicological risk. The principal organochlorine compounds found in sediments were $\gamma-\mathrm{HCH}, \delta-\mathrm{HCH}, \mathrm{p}, \mathrm{p}$ '-DDT and the endosulfan sulfate; these xenobiotics come from agriculture lands near the river and lake, used intensively, and most probably carried by the rain and rain flows into the main water body. In the tilapias tissue, p,p'-DDD y $\delta$-HCH were detected. The average concentrations of organochlorine pesticides in sediments were within the internacional limits for freshwater benthonic fauna, although lindane $(\gamma-\mathrm{HCH})$ was near the limit. The fish were above the criteria established in the local legislation (NOM-027-SSA1-1993 y NOM-028-SSA1-1993). Rev. Biol. Trop. 56 (3): 1381-1390. Epub 2008 September 30.
\end{abstract}

Key words: Organochlorine pesticides, sediment, particulate organic carbon, Metztitlán, México.

The organochlorine pesticides (OP) are very stable molecules, due to this stability; they are very resistant in the environment and highly related to fat tissues with a wide diffusion property and an average time life higher then 10 years. Their long term impacts in the systems cannot be easily determined (Brown 1978, Li et al. 2001, Jiries et al. 2002, Sun et al. 2005). The physical and chemical characteristics of pesticides are important to determine its activity and effects on different ecosystems, helping to prevent or reduce the problems generated by this type of pollution (Jiries et al. 2002, Hoekstra et al. 2003, Miersma et al. 2003). Recently, scientific studies have showed the serious consequences in the use of these chemicals (OP). The human being has started to control in the use of OP in order to avoid this type of pollution (Sanpera et al. 2002, Pesando et al. 2004, Vega et al. 2006).

These compounds have great affinity for fatty molecules what makes it easier to be accumulated in the fat tissue of organisms; as a consequence they can be biomagnify along the food chain, where its degradation products are more toxic or permanent than the original 
compound (Henao et al. 2004, Sunyer 2000). In fish, the tissue accumulation grade in males is proportional to the age (Tricklebank et al. 2002) and its trophic level (Manirakiza et al. 2002). Pesticides affect mostly the reproduction phase, for example DDT, DDE and DDD modify the time in which the vitelline sac is absorbed, besides other OP hurt different vital organs such as the kidney, the brain, the muscles, gonads, intestines and gills (Jonson and Toledo 1993). It has been found that some fish in Venezuela in captivity developed tumors, liver necrosis and skeleton abnormalities due to being exposed to these types of compounds (Urdaneta et al. 1995).

In the aquatic systems most OP have short time of residence in the water because they are quickly adsorbed to particulate material which is suspended in water and also to the sediment and organisms (Froilan et al. 2005, Ribeiro et al. 2005, Pazou et al. 2006). Thus, benthic species are directly in contact with higher concentrations of pesticides adsorbed, than those species near the water surface where levels of suspended sediments are lower (Wurl et al. 2006).

The Vega of Metztitlán is located in the central part of the country and its economic base is mainly agriculture, but recently, aquaculture related activities have been developed (SEMARNAP 1999). This lake is located $20^{\circ}$ $40^{\prime}$ and $20^{\circ} 42^{\prime} \mathrm{N}$ and $98^{\circ} 50^{\prime}$ and $98^{\circ} 53^{\prime} \mathrm{W}$, at $1264 \mathrm{msnm}$ which flooded surface is 2 937.20 ha. The importance of the lagoon is related to its buffering capacity for the Reserva de la Biósfera de Metztitlan, besides of having a great variety of endemic flora and fauna (CONAMP 2004, RAMSAR 2004).

The objective of this study was to identify and measure the OP in recent sediments collected in the lake of Metztitlan, Hgo. and to observe its relation with the sedimentary organic material, and evaluate the content of those compounds in fish muscle and determine the potential risk of the compounds founded in this ecosystem.

\section{MATERIALS AND METHODS}

Sediments were collected using a van Veen dredger during November (2001), April and June (2002). After collection all samples were stored in glass jars and frozen until further analysis. $100 \mathrm{~g}$ of dried sediments from each sampling site were pulverized and sieved $(250 \mu \mathrm{m})$. The muscle samples were obtained from commercial captures during April and July (2002). The purification of OP in sediment and fishes was achieved in accordance with the UNEP/ IAEA method (1982) and the UNEP/FAO/ IOC/IAEA method (1986). $3 \mathrm{~g}$ of sample were extracted in a soxhlet device using n-hexane for eight hours; one spiked reagents blank was performed for each five samples. The extract was concentrated in a rotovaporator at $30^{\circ} \mathrm{C}$ and $40 \mathrm{psi}$; for the organisms, a lipid hydrolysis was done adding $1 \mathrm{~mL} \mathrm{H}_{2} \mathrm{SO}_{4}$ and centrifuged (50 $\mathrm{rpm} / 5 \mathrm{~min}$ ), until a translucid stage is reach. Once extracts were obtained (sediments/ organisms) they were purified through adsorption chromatography in a column packed with florisil and anhydrous sodium sulfate previously purified, activated and deactivated to separate the polychlorinated biphenyls (PCB, Fraction 1) from the organochlorine pesticides (OP, Fraction 2). The sedimentary extract was eluted with $60 \mathrm{~mL}$ n-hexane to obtain fraction 1 and afterwards with $50 \mathrm{~mL}$ of a mixture of n-hexane: anhydrous ethyl ether (9:1) and 20 $\mathrm{mL}(8: 2)$ to obtain fraction 2; meanwhile muscle samples were eluted with $10 \mathrm{~mL}$-hexane to obtain fraction 1 and afterwards with $10 \mathrm{~mL}$ of a mixture of n-hexane: anhydrous (75:25) to obtain fraction 2 . The fraction 2 was concentrated under an ultrapure $\mathrm{N}_{2}$ flow and injecting $1 \mu \mathrm{L}$ of this concentrate into a gas chromatograph (Hewlett Packard mod 5890 series II) equipped with an electron capture detector $\left(\mathrm{ECD}^{63} \mathrm{Ni}\right)$, and a HP-5 capillary column of fused silica, with 5\% methyl-phenyl-silicon phase $(30 \mathrm{~m}, 0.25 \mathrm{~mm}$ id and $0.25 \mu \mathrm{m}$ layer thickness); He (1 $\left.\mathrm{mL} \mathrm{min}^{-1}\right)$ was used as carrier gas and $\mathrm{N}_{2}\left(30 \mathrm{~mL} \mathrm{~min}^{-1}\right)$ was used as auxiliary 
gas. Working conditions during analyses were: $90^{\circ} \mathrm{C}-2 \mathrm{~min}, 30^{\circ} \mathrm{Cmin}^{-1}-180^{\circ} \mathrm{C}-0 \mathrm{~min}, 3^{\circ} \mathrm{Cmin}^{-}$ ${ }^{1}-270^{\circ} \mathrm{C}-0 \mathrm{~min}$, the injector temperature was $260^{\circ} \mathrm{C}$ and the detector's temperature was $320^{\circ} \mathrm{C}$. To quantify compounds, an internal standard method based on retention time and specific area of the compounds was used. This standard contains a mixture of 16 compounds (Chem. Service Inc.), at a $20 \mathrm{ng} \mathrm{mL}^{-1}$ concentration. The recovery percentage was between $90-92 \%$. The organochlorine pesticides assessed were: $\alpha-\mathrm{HCH}, \beta-\mathrm{HCH}, \gamma-\mathrm{HCH}$, $\delta$-HCH (alicyclics), p,p'-DDT, p,p'-DDE, p,p'DDD (aromatics), Heptachlor, Heptachlor epoxide, Aldrin, Dieldrin, Endrin, Endrin aldehyde, Endosulfan I, Endosulfan II and Endosulfan sulphate (cyclodienes). The analytical performance of results was accredited through the participation of the laboratory in an International Intercalibration Exercise coordinated by the International Atomic Energy Agency (IAEA 1997) for organochlorine pesticides.
The concentrations obtained had a normal distribution. Parametric tests were performed using software Stata (2001), such as the ANOVA and $t$-test with $\alpha$ of 0.05 to verify any difference between seasons (muscle and sediments), concentration of each compound per sampling period and among the different chemical families (sediments).

Determination of particulate organic carbon (POC) was performed according to the oxidative colorimetric method proposed by Gaudette et al. (1974).

\section{RESULTS}

The average of OP observed during the three climatic periods were not significantly different among them (ANOVA: $F=2.14, \mathrm{p}=0.15$ ) and among sample sites $(F=0.65, \mathrm{p}=0.78)$.

The highest levels from all three sampling periods corresponded to $\gamma-\mathrm{HCH}, \mathrm{p}, \mathrm{p}$ '-DDT and $\delta$-HCH (Table 1).

TABLE 1

Average concentration of organochlorine pesticides $\left(n g g^{-1}\right.$, dry weight, mean $\left.\pm S E\right)$ in surface sediment layers

$\begin{array}{lc}\text { Compound } & \text { November (2001) } \\ \alpha-\mathrm{HCH} & 0.45 \pm 0.30 \\ \beta-\mathrm{HCH} & * \\ \gamma-\mathrm{HCH} & 1.52 \pm 0.67 \\ \delta \text {-HCH } & 2.04 \pm 0.95 \\ \text { p,p'-DDT } & 0.62 \pm 0.38 \\ \text { p,p'-DDE } & * \\ \text { p,p'-DDD } & 0.22 \pm 0.15 \\ \text { Heptachlor } & 0.28 \pm 0.28 \\ \text { Heptachlor epoxide } & 0.05 \pm 0.05 \\ \text { Aldrin } & * \\ \text { Dieldrin } & * \\ \text { Endrin } & 0.14 \pm 0.14 \\ \text { Endrn aldehyde } & * \\ \text { Endosulfan I } & 0.09 \pm 0.09 \\ \text { Endosulfan II } & * \\ \text { Endosulfan sulphate } & 1.10 \pm 0.56 \\ \text { Average total concentration } & 6.51 \pm 1.37 \\ *=\text { Not detected }\left(<0.01 \mathrm{ng} \mathrm{g}^{-1}\right) . & \end{array}$

$\begin{array}{cr}\text { April (2002) } & \text { July (2002) } \\ 0.02 \pm 0.02 & 0.31 \pm 0.15 \\ 0.69 \pm 0.47 & 0.16 \pm 0.10 \\ 0.42 \pm 0.24 & 0.43 \pm 0.27 \\ 0.18 \pm 0.18 & 0.37 \pm 0.16 \\ 0.23 \pm 0.15 & 0.75 \pm 0.50 \\ * & 0.05 \pm 0.03 \\ 0.33 \pm 0.14 & 0.31 \pm 0.12 \\ * & 0.57 \pm 0.28 \\ * & 1.16 \pm 0.52 \\ * & 0.23 \pm 0.22 \\ 0.10 \pm 0.10 & 0.17 \pm 0.09 \\ * & 0.03 \pm 0.02 \\ * & 0.07 \pm 0.04 \\ * & 0.27 \pm 0.15 \\ * & * \\ 0.27 \pm 0.21 & 0.14 \pm 0.8 \\ 2.24 \pm 0.48 & 5.02 \pm 1.45\end{array}$


The compounds below the analytical detection limit $\left(<0.01 \mathrm{ng} \mathrm{g}^{-1}\right)$ were: Heptachlor epoxide, $\alpha-\mathrm{HCH}$, and endrin. The only compound that was not detected at all was endosulfan II $\left(<0.01 \mathrm{ng} \mathrm{g}^{-1}\right)$, most probably due to its recent application; hence, not enough time has elapsed for its degradation as indicated by the survey performed (Fernández-Bringas 2004) on the use of agrochemicals in The Vega of Metztitlan (Table 1).

During November (2001) and April (2002) the alicyclic group predominated, whereas during July (2002) the aromatic compounds predominated (Table 2). It must be mentioned that these families have the highest environmental and public health risks, due to their high carcinogenic effect (Dich et al. 1997, IARC 2002).
The POC percentages in the surface sediment layers of the Metztitlan Lake during the dry season (November 2001) ranged from $0.59 \%$ in station 5 to $1.83 \%$ station 1 , located at the end of the lake, near the overflow channel (Fig. 1), showed the highest percentage for this season; the average at this sampling point was $1.06 \% \pm 0.16$. In contrast, in April (2002), POC levels ranged from $0.53 \%$ in station 6 to $2.61 \%$ in station 2 at the end of the lake (Fig. 1 ), the average for this season was $1.03 \% \pm$ $0.19 \mathrm{ng} \mathrm{g}^{-1}$. Only one sampling was performed during the rainy season (July, 2002), recording values of $0.64 \%$ at site 6 to $1.51 \%$ in station 13 located on the Venados River just before de San Cristobal community. The average for this sampling was $1.02 \pm 0.09 \%$. Particular

TABLE 2

Average concentration $\left(n g g^{-1}\right.$, dry weight, mean $\left.\pm S E\right)$ per chemical family of the organochlorine pesticides in the surface sediments layer

Chemical family

Alicyclic

Aromatics

Cyclodienes
November (2001)

$9.01 \pm 3.65$

$2.53 \pm 1.44$

$1.66 \pm 1.32$
April (2002)

$3.60 \pm 1.62$

$2.06 \pm 0.45$

$0.45 \pm 0.44$
July (2002)

$3.81 \pm 0.70$

$4.46 \pm 2.47$

$3.51 \pm 1.46$

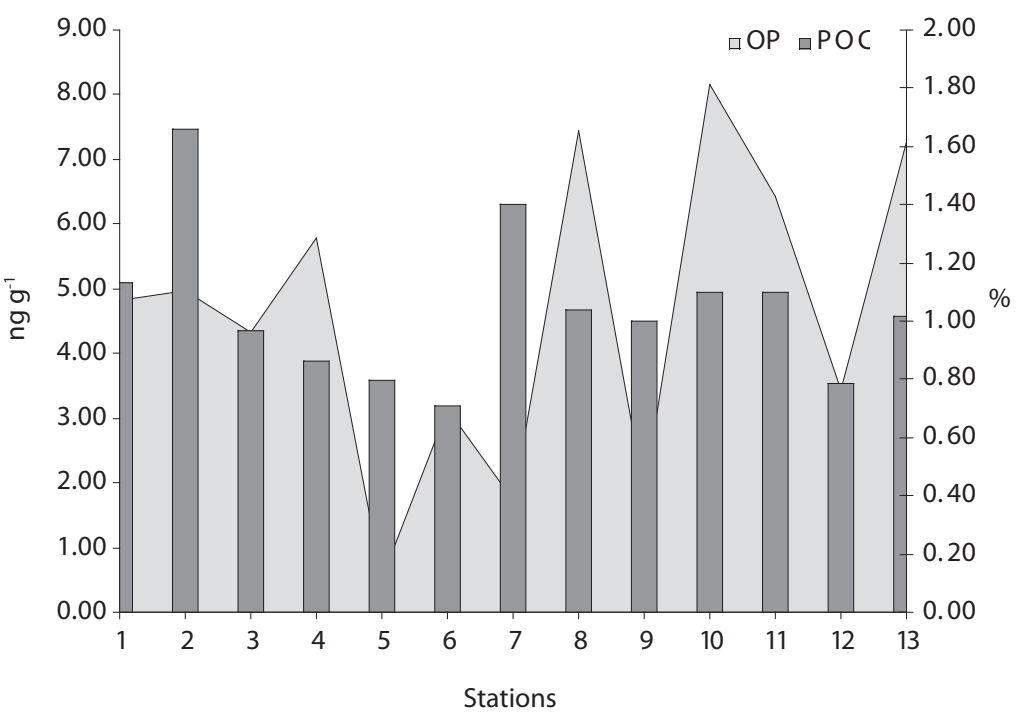

Fig. 1. Correlation between organochlorine pesticides ( $\left.\mathrm{ng} \mathrm{g}^{-1}\right)$ and particulate organic carbon (\%), in recent sediments (dry weight) per sampling station in the Metztitlán Lake, Hidalgo. 
sites of POC deposition were detected as follow: station 1 for the November 2001, station 2 for April 2002, and station 13 for July 2002, respectively.

In the muscle samples, important differences among compounds were obtained as follow: $\delta$-HCH $(t=-4.2294, \mathrm{p}=0.002)$ and $\mathrm{p}, \mathrm{p}-\mathrm{DDD}(t$ $=-3.7984, p=0.003)$, what it could be due to the bioavailability at different seasons.

The predominant compounds located in the muscle during April 2002, were p,p'-DDD with $1.35 \pm 0.42 \mathrm{ng} \mathrm{g}^{-1}$ and the $\delta-\mathrm{HCH}$ with $1.06 \pm 0.79 \mathrm{ng} \mathrm{g}^{-1}$, the average was $2.69 \pm$ $1.27 \mathrm{ng} \mathrm{g}^{-1}$. For July 2002, the predominant compounds were $\delta-\mathrm{HCH}$ with $6.97 \pm 1.07 \mathrm{ng}$ $\mathrm{g}^{-1}$ and $\mathrm{p}, \mathrm{p}$-DDD with $6.65 \pm 1.19 \mathrm{ng} \mathrm{g}^{-1}$ with an average concentration of $14.75 \pm 2.38 \mathrm{ng} \mathrm{g}^{-1}$ (Table 3).

\section{DISCUSSION}

Of the 16 analyzed compounds, 94\% of them were present, only endosulfan II was not detected $\left(<0.01 \mathrm{ng} \mathrm{g}^{-1}\right)$. The most common compounds found in each group of samples were: $\alpha-\mathrm{HCH}, \gamma-\mathrm{HCH}, \delta-\mathrm{HCH}, \mathrm{p}, \mathrm{p}$-DDT, p,p'-DDD, and endosulfan sulphate; showing the highest concentrations compared to the other detected. Comparison between the OP levels in the sediments from the Metztitlan system, Hidalgo, and the levels previously reported for the Catemaco Lake, Veracruz (a similar ecological system with such information for the country) (Calderón-Villagómez et al. 2001), reveals that the values for the persistent compounds, such as dieldrin, DDT and its metabolite DDE, in the Meztitlan Lake

TABLE 3

Average concentration of organochlorine pesticides (ng $g^{-1}$, dry weight, mean $\pm S E$ ) in muscle samples from Oreochromis spp

$\begin{array}{lcc}\text { Compound } & \text { April (2002) } & \text { July (2002) } \\ \alpha-\mathrm{HCH} & 0.20 \pm 0.07 & * \\ \beta \text {-HCH } & * & * \\ \gamma \text {-HCH } & 0.12 \pm 0.12 & 0.48 \pm 0.20 \\ \delta \text {-HCH } & 1.06 \pm 0.79 & 6.97 \pm 1.07 \\ \text { p,p'-DDT } & 0.08 \pm 0.05 & * \\ \text { p,p'-DDE } & 0.26 \pm 0.26 & 0.65 \pm 0.40 \\ \text { p,p'-DDD } & 1.35 \pm 0.42 & 6.65 \pm 1.19 \\ \text { Heptachlor } & * & * \\ \text { Heptachlor epoxide } & * & * \\ \text { Aldrin } & * & * \\ \text { Dieldrin } & 0.20 \pm 0.07 & * \\ \text { Endrin } & 0.08 \pm 0.04 & * \\ \text { Endrn aldehyde } & * & * \\ \text { Endosulfan I } & * & * \\ \text { Endosulfan II } & * & * 14.75 \pm 2.38 \\ \text { Endosulfan sulphate } & * & \\ \text { Average total concentration } & 2.69 \pm 1.27 & * \\ *=\text { Not detected }\left(<0.01 \mathrm{ng} \mathrm{g}^{-1}\right) . & & *\end{array}$


are one order of magnitude below the concentrations detected in the Catemaco Lake sediments, suggesting that the system evaluated here is less contaminated.

Field surveys were performed regarding the use of agrochemicals in La Vega de Metztitlan, to verify which compounds have been used in the agricultural fields near the lake, showing a good correlation with those found in the sediments analyzed. For the first semester of 2003 the agricultural products were beans, long-beans, corn, string-beans, zucchini, chili, serrano-chili, jalapeño-chili, tomatoes, potatoes, and sorgum (Fernández-Bringas 2004). For these products, the pesticides used and sold in the study area were: Thiodan ${ }^{\mathrm{TM}}$, Traser $^{\mathrm{TM}}$, Benlates ${ }^{\mathrm{TM}}$, Lannate ${ }^{\mathrm{TM}}$, Vydate ${ }^{\mathrm{TM}}$, Nuvacron $^{\mathrm{TM}}$, and Arribo ${ }^{\mathrm{TM}}$. Thiodan ${ }^{\mathrm{TM}}$ was the only compound registered in the lake sediments with a high total concentration $\left(0.27 \mathrm{ng} \mathrm{g}^{-1}\right)$; its active ingredient is endosulfan (FernándezBringas 2004).

Sediments did not showed significant seasonal differences, therefore it can be inferred that the use of agrochemicals is continuous along the year and rains do not affect directly the presence or absence of these compounds in the lake, which was confirmed by the information provided by the survey.

During these different climatic periods, mobility of the chlorinated compounds was found within the watershed, this is due to the fact that from the site of the Venados River mouthing (southeast zone) to the far end of the lake (north zone), where an overflow channel is located, the excess water from the dam is drained, and because of these a dynamic current is created that promote the output of suspended matter from the water column and of sedimentary material. The use of organochlorine pesticides at the national level is regulated by the Official Catalogue of Pesticides (CICOPLAFEST 1998), which establishes that the banned compounds are aldrin, dieldrin, and endrin; among the restricted ones are DDT, HCH and Lindane $(\gamma-\mathrm{HCH})$. It is important to highlight that no maximal permissible levels exist in Mexico for the use of these substances; hence, it was compared the data obtained with the international criteria provided by NOAA (1999) regarding to freshwater sediments. The only value that exceeded these criteria was lindane, with an average concentration of $1.52 \pm 0.67 \mathrm{ng} \mathrm{g}^{-1}$ (November 2001); the interval at which adverse effects have been observed in benthic organisms is $0.94-1.38 \mathrm{ng} \mathrm{g}^{-1}$. More recently (October 2004) Mexico proposed an Action Plan to the Environmental Cooperation Commission (USA, Canada and Mexico) to eliminate the use of lindane in agriculture and public health campaigns, because of its toxicity.

At a point level, at least three stations during the three sampling periods exceeded this criteria of sedimentary quality in the Metztitlan Lake; for example, for November (2001), sites $1,2,12$, and 13 had two- to four-times higher values than the established criteria (Long et al. 1995). For April (2002), sites 1 and 6 were higher, and for July (2002) sites 11 and 13 were two times higher than the reference values (Long et al. 1995, Buchman 1999).

Because organic carbon in aquatic sediments enables the storage of diverse ecological relevant substances and materials, as well as of those dangerous compounds as organochlorine pesticides, it is important to assess the relation between these two environmental parameters. The equilibrium in any aquatic system is not constant along time and the primary production processes vary in terms of efficiency and total net production, which implies that the magnitude of POC as nutrient is not similar during all the seasons, although there are lacustrine systems that depend more on these supplies than others (Jansson et al. 2000). Besides, there are other factors influencing total concentration of POC in an aquatic system, such as the assimilation rate of dissolved inorganic carbon and its transformation into particulate organic carbon (Jansson et al. 2000).

In this study, the small variability in OP values can be explained by the large input of organic matter to the system (Pérez-Rojas 
2001), in which percentage of POC is very low, suggesting that this fraction is being used rapidly and this might be taking place continuously along the year.

Figure 1 showed the global behavior of POC observed in the Metztitlan lacustrine system; the average percentages showed maximal values at station 2 with $1.66 \%$ and a minimal of $0.71 \%$ at station 6 . From a seasonal point of view, the highest POC values (Fig. 1) were recorded in November (2001) at station 1 with $1.83 \%$; in April (2002) at station 2 with $2.61 \%$; in July (2002) at station 13 with $1.51 \%$. Whereas for the chlorinated compounds the highest values were detected in November (2001) at station 13 (12.58 $\left.\mathrm{ng} \mathrm{g}^{-1}\right)$, April (2002) at station 1 (5.63 $\left.\mathrm{ng} \mathrm{g}^{-1}\right)$, and July (2002) at station $8\left(18.49 \mathrm{ng} \mathrm{g}^{-1}\right)$ respectively.

Although no global correlation was found between the OP and POC since the coefficient was low and not statistically significant, this analysis allowed to identify specific accumulation sites of each of the matrices, revealing that the points of supply for each of the variables are different and continuous. It is worthwhile mentioning that the correlation found in April (2002) was inverse between both matrices, indicating that at the sites with the highest concentration of OP had a lower POC concentration.

The most common compounds detected in April (2002) were p,p'-DDD, $\delta-H C H$ and p,p'-DDE (Table 3); while for July (2002) were $\delta-\mathrm{HCH}, \mathrm{p}, \mathrm{p}$-DDD (Table 3), which are characterized by being highly persistent and bioaccumulated. Although a low variability of analytes was detected $(50 \%$ and $25 \%$ respectively) for both sampling seasons, the concentration of OP in muscle showed an important difference per compound such as $\alpha-\mathrm{HCH}(t=$ $-4.2294, \mathrm{p}=0.002)$ and $\mathrm{p}, \mathrm{p}-\mathrm{DDD}(t=-3.7984$, $\mathrm{p}=0.003)$. On the other hand, the chemical family and climatic season did not showed differences (Table 4).

In Mexico, there are official norms that regulate the chemical content in fishery products for human consumption, the NOM-027SSA1-1993 for the fresh-refrigerated and
TABLE 4

Average concentration (ng $g^{-1}$, dry weight, mean \pm SE) per chemical family of organochlorine pesticides in the muscle sample from Oreochromis spp

$\begin{array}{lcc}\text { Chemical family } & \text { April (2002) } & \text { July (2002) } \\ \text { Alicyclic } & 1.37 \pm 0.97 & 9.32 \pm 8.53 \\ \text { Aromatics } & 6.78 \pm 1.58 & 12.17 \pm 10.58 \\ \text { Cyclodienes } & 1.08 \pm 0.09 & * \\ *=\text { Not detected }\left(<0.01 \mathrm{ng} \mathrm{g}^{-1}\right) . & \end{array}$

freezed aquatic products, and NOM-028SSA1-1993 for the preserved ones, specify that those products must not contain organochloride pesticide such as aldrin, dieldrin, endrin, heptachlor chlordecon (kepone) or others forbidden in the Official Catalogue of Pesticides CICOPLAFEST (1998). The above mentioned OP were found in the samples analyzed. At the international level, the Food and Drug Administration of the United States (US-FDA 1998) established that a level for Aldrin/ Dieldrin $300 \mathrm{ng} \mathrm{g}^{-1}$, for the family of DDT $5000 \mathrm{ng} \mathrm{g}^{-1}$ and for the family of heptachlor $300 \mathrm{ng} \mathrm{g}^{-1}$. Comparing with the registered data in the Metztitlán system none of the levels were above the reference values.

The food is the main route of intake of OP in these organisms and the second route is the water filtration; it is important to take into account information related to food dynamics of each species involved. In this case, the Oreochromis spp have a tendency to maintain a similar proportion between the organic matter and the rest of vascular plants in their diet, either in the dry or rainy season (Jiménez 1999). This proportion is also determined according to the availability and abundance of food (Spataru 1976, Hylsop 1980).

\section{ACKNOWLEDGMENTS}

We thank Gabriel Núñez-Nogueira for his suggestions, critical reading and improving of the manuscript. 


\section{RESUMEN}

El presente trabajo se llevó a cabo en la cuenca lacustre de Metztitlán, Hgo. Se realizaron tres colectas de sedimentos recientes en noviembre (2001), abril y julio (2002) y dos colectas para organismos en abril y julio (2002). Los análisis se hicieron siguiendo la metodología para sedimentos propuesta por UNEP/IAEA (1982) y para tejido de organismos por UNEP/FAO/IOC/IAEA (1986). Se identificaron y cuantificaron tres familias químicas de plaguicidas organoclorados, para determinar el posible riesgo toxicológico de los sedimentos y de organismos en capturas comerciales. Los principales compuestos clorados en sedimentos fueron el $\gamma-\mathrm{HCH}, \delta-\mathrm{HCH}, \mathrm{p}, \mathrm{p}^{\prime}-\mathrm{DDT}$ y el sulfato de endosulfán; estos xenobióticos provienen de las zonas de cultivos aledañas al río y al lago, con un uso intensivo, probablemente transportados por lluvias y descargas fluviales hacia el cuerpo lacustre y en el tejido de organismos se detectaron principalmente el p,p'-DDD y $\delta$-HCH. Las concentraciones promedio de plaguicidas clorados en sedimentos no rebasaron los límites establecidos en los criterios de calidad ambiental internacionales para provocar efectos nocivos en la biota bentónica de los sistemas dulceacuícolas, aunque de manera puntual el lindano $(\gamma-\mathrm{HCH})$ registró niveles cercanos a dichos límites. Las tilapias rebasaron los criterios existentes en las Normas Oficiales Mexicanas (NOM-027-SSA1-1993 y NOM-028SSA1-1993).

Palabras clave: Plaguicidas organoclorados, sedimentos, tilapia (Oreochromis spp), carbono orgánico particulado, Metztitlán, México.

\section{REFERENCES}

Buchman, M.F., 1999. NOAA Screening Quick Reference Tables, NOAA HAZMAT report 99-1, Seattle WA, Costal Protection and Restoration Division, National Oceanic and Atmospheric Administration. Seattle, Washington, USA. 12 p.

Calderón-Villagómez, H.E., R. Gónzalez-Enriquez \& C. Duran de Basúa. 2001. Plaguicidas en sedimentos y organismos acuáticos del lago de Catemaco, Veracruz, México. Rev. Int. Contam. Ambient. 17: 23-3.

CICOPLAFEST: Comisión Intersecretarial para el Control del Proceso y Uso de Plaguicidas, Fertilizantes y Sustancias Tóxicas. 1998. Catálogo oficial de plaguicidas. Secretaria del Ambiente, Recursos Naturales y Pesca/ Secretaría de Comercio y Fomento Industrial/ Secretaría de Agricultura, Ganadería y Desarrollo Rural/ Secretaría de Salud, Mexico.

Dich, J, S.H. Zahm, A. Hanberg \& H.O. Adami, 1997. Pesticides and cancer. Cancer Causes Control 18 : 420-443.
Fernández-Bringas L.M. 2004. Evaluación de plaguicidas organoclorados en el sistema lacustre de Metztitlán, Hidalgo. MS (Biology) Thesis. Universidad Autónoma Metropolitana-Iztapalapa, Iztapalapa, México D.F., Mexico. 114 p.

Froilan P., M. Robledo, B. Romero, C. Zambrano, Z. Arangure \& M. Jáuregui. 2005. Plaguicidas organoclorados en sedimentos, materia particulada suspendida y biota en la laguna San Pedro, CEMIC-UAN, San Pedro Lagunillas, Nayarit, México.

Gaudette H.E., W.R. Fligat, L. Torner \& D.W. Folger. 1974. An inexpensive titration method for the determination of organic carbon in recent sediments. J. Sediment Petrol. 44: 249-253.

Henao S. \& O. Nieto. 2004. Organoclorados. In: Curso de Autoinstrucción en diágnostico, tratamiento y prevención de intoxicaciones agudas causadas por plaguicidas. Centro Panamericano de Ingeniería Sanitaria y Ciencias del Ambiente (CEPIS/OPS), N.W, Washington D.C., USA.

Hylsop, E.J. 1980. Stomach contents analysis-a review of methods and their application. J. Fish. Biol. 17:411429.

INE: Instituto Nacional de Ecología. 2000. Manual de trabajo: Características de peligrosidad ambiental de plaguicidas. $1^{\circ}$ Edición. Coyoacán, México D.F., Mexico. 282 p.

Hoekstra P.F., T.M. O’Hara, A.T. Fisk, K. Borga, K.R. Solomon \& D.C.G. Muir. 2003. Trophic transfer of persistent organochlorine contaminants (Ocs) within an Arctic marine food web from the southern BeaufortChukchi Seas. Environ. Pollut 124: 509-522.

IAEA: International Atomic Energy Agency. 1997. Worldwide and regional intercomparison for the determination of organochlrine compounds and petroleum hydrocarbons in focus sample. Report 63, Marine Environmental Laboratory, Monaco. 114p.

IARC: International Agency for Research on Cancer. 2002. Monographs on the evaluation of carcinogenic risks to humans and their supplements: a complete list. Available on- line: last update: December $4^{\text {th }}, 2002$. (Downloaded: December $10^{\text {th }}, 2002$, http://monographs.Iarc.f1/monoeval/allmonos.html)

Jansson M., A.K. Bergstroem, P. Blomqvist \& S. Drakare. 2000. Allochthonous organic carbon and phytoplankton/bacterioplankton production relationships in lakes. Ecol. 81: 3250-3255.

Jímenez B.L. 1999. Análisis de la pesquería de Tilapia en la presa Adolfo López Mateos, Michoacán Guerrero. 
Tesis Doctoral en Ciencias del Mar. UNAM, México D.F., Mexico. 178 p

Jiries A.G., F.M. Nasir \& F. Beese. 2002. Pesticide and heavy metals residue in wastewater, soil and plants in waste disposal site near Al-Lajoun Valley, Karak/ Jordan. Water Air Soil Pollut. 133: 97-107.

Jonson C.M. \& M.T. Toledo. 1993. Bioaccumulation and elimination of endosulfan in the fish Yellow tetra (Hyphessobrycon bifasciatus). B Environ Contam Tox. 50:572-577.

Li X.D., B.X. Mai, G. Zhang, G.Y. Sheng, J.M. Fu, S.M. Pan, O.W.H. Wai \& Y.S. Li. 2001. Distribution of organochlorine pesticides in a sediment profile of the Pearl River Estuary. B Environ Contam Tox. 67: 871-880.

Long E.R., D.D. Macdonald, S.L. Smith \& F.D. Calder. 1995. Incidence of adverse biological effects within ranges of chemical concentrations in marine and estuarine sediments. Environ. Manage. 19: 81-97.

Manirakiza P., A. Covaci, L. Nizigiymana, N.G. Takimazi \& P. Schepens. 2002. Persistent chlorinated pesticides and polychlorinated biphenyls in selected fish species from Lake Tanganyika, Burundi, Africa. Environ. Pollut. 117:447-455.

Miersma N.A., C.B. Pepper \& T.A. Anderson. 2003. Organochlorine pesticides in elementary school yards along the Texas-Mexico border. Environ. Pollut. 126: $65-71$.

NOAA: National Oceanic and Atmospheric Administration. 1999. Sediment Quality Guidelines developed for the National Status and Trends Program, $10 \mathrm{p}$. Available on-line: last updated: December $6^{\text {th }}, 1999$, (Downloaded: October $24^{\text {th }}, 2002$, http://response. restoration.noaa.gov/cpr/sediment/SPQ.pdf)

NOM-027-SSA1-1993. 1994. Bienes y servicios. Productos de la pesca. Pescados frescos-refrigerados y congelados. Especificaciones sanitarias. Mexican Goverment, Mexico D.F., Mexico.

NOM-028-SSA1-1993. 1994. Bienes y servicios. Productos de la pesca. Pescados en conserva. Especificaciones sanitarias. Mexican Goverment, Mexico D.F., Mexico.

Pazou Y. E., C. Van Gestel, H. Ahissou, P. Laleye, S. Arpona, B. van Hattum , K. Swart \& M. van Straalen. 2006. Organochlorine and organosphorous plaguicida residues in the Oumé River catchment in the Republic of Benin. Environ. Inter. 32:616-623.

Pérez-Rojas A., C.J.L. García \& R.C. Salas. 2002. Morfometría y sedimentos recientes de un lago del altiplano central mexicano. Resúmenes del II Congreso Nacional de la Asociación Mexicana de Limnología, México D.F., México.

Pesando D., S. Robert, P. Huitorel, E. Gutknecht, L. Pereira, J-P. Girard \& B. Chiapa. 2004. Effects of methoxychlor, dieldrin and lindane on sea urchin fertilization and early development. Aquat. Toxicol. 66: $225-239$

RAMSAR: The Ramsar Convention on Wetlands. 2004. Available on-line, downloaded: December $10^{\text {th }}, 2004$, http://www.ramsar.org/wwd2004_rpt_mexico1bis. htm

Ribeiro O.C.A., Y. Vollaire, Ch. Sanchez \& H. Roche. 2005. Bioaccumulation and the effects of organochlorine pesticides, PAH and heavy metals in the Eel (Anguilla anguilla) at the Camargue Nature Reserve, France. Aquat. Toxicol. 74: 53-69.

Sanpera C., X. Ruiz, G.A. Llorente, L. Jover \& R. Jabeen. 2002. Persistent organochlorine compounds in sediment and biota from the Haleji Lake: a wildlife sanctuary in south Pakistan. Bull. Environ. Contam. Toxicol. 68: 237-244.

StataCorp. 2001a. Stata Statistical Software: Release 7.0 References Manual. College Station 1(A-G), Texas, USA. p. 164-174.

StataCorp. 2001b. Stata Statistical Software: Release 7.0. College Station Stata Corporation, Texas, USA.

SEMARNAP: Secretaría del Ambiente Recursos Naturales y Pesca. 1999. Documento técnico justificativo para la creación de la Reserva de la Biosfera Barranca de Metztitlán, Hidalgo, Mexico. 298 p.

Spataru P. 1976. Some aspects of natural feed and feeding of Tilapia Galilea y T. Aurea. in lake Kineret. Bamidgeh. 28: 12-17.

Tricklebank K.A., M.J. Kingsford \& H.A. Rose. 2002. Organochlorine pesticides and hexachlorobenzene along the central coast of New South Wales: multiscale distributions using the territorial damselfish Parma microlepis as an indicator. Environ. Pollut. 116: 319-335.

Sun F., S.S. Wong, C.G. Li \& S.N. Chen. 2005. A preliminary assessment of consumer's exposure to pesticide residues in fisheries products. Chemosphere. 62: 674-680

Sunyer J. 2000. Los organoclorados y su neurotoxicidad. Instituto Municipal de Investigación Médica. Cataluña, Barcelona, España. 5 p. 
UNEP/FAO/IOC/IAEA: United Nations Environment Programme/ Food and Agriculture Organization/ Intergovernamental Oceanographic Commission of Unesco( United Nations Educational Scientific and Cultural Organization)/ International Agency of Energy Atomic. 1986. Determination of DDT's, PCB's in selected marine organisms by packed column gas-chromatography. Reference Methods for Marine Pollution Studies. No. 14.

UNEP/IAEA: United Nations Environment Programme/ International Agency of Energy Atomic. 1982. Determination of DDT's, PCB's and other hydrocarbons in marine sediments by gas liquid chromatography. Reference methods for marine pollution studies. No. 17.

Urdaneta H., B. Medina \& Z. Acosta. 1995. Organochlorine compounds in fish from a farming station in the municipality of Paéz, state of Zulia, Venezuela. Bull. Environ. Contam. Toxicol. 54:703-710.
US-FDA: United States Food and Drug Administration. 1984. Action level from Chemicals and poisonous substances. US Department of Health, Education and Welfare, Public Health Service. New York, New York, USA.

Vega M.D., F.Z. Sosa \& R.J. Santana. In press. Microwave assisted micellar extraction coupled with SPME for the determination of organochlorine plaguicidas in soil samples. Anal Chim Acta.

Wurl O., J. Philip \& Obbard. 2006. Distribution of organochlorine compounds in the sea-surface microlayer, water column and sediment of singapore's coastal environment. Chemosphere. 62:1105-1115.

\section{INTERNET REFERENCE}

CONANP: Cooperación en Áreas Naturales Protegidas. 2004. http://conanp.gob.mx/dcei/hum/index.htm (downloaded 26 May 2008) 